\title{
Making Education Game to Choose Healthy Snacks for Children
}

Vania Wahyu Febriani

Department of Information System, Faculty of Computer Science

Soegijapranata Catholic University, Semarang, Indonesia, 50234

vania.wahyu@gmail.com

\section{T. Brenda Chandrawati}

Department of Information System, Faculty of Computer Science

Soegijapranata Catholic University, Semarang, Indonesia, 50234

brenda@unika.ac.id

\begin{abstract}
Albertus Dwiyoga Widiantoro
Department of Information System, Faculty of Computer Science

Soegijapranata Catholic University, Semarang, Indonesia, 50234

yoga@unika.ac.id
\end{abstract}

\begin{abstract}
One of the learning media is game. Games that can be used as a learning tool can be called as education games. Because children like games, games can make positive effect for them. Children can study while they are playing games.

Education game that has theme about snacks for children is still rarely found. Unfortunately, children from elementary school have a habit to buy and eat snacks without paying attention to snacks hygiene and health. For this reason, education about choosing hygiene and healthy snack for children should be made. The aim of this games is to make children more careful about choosing snacks that they will eat .

This paper will explain how to make education game about snacks and to prove that this game can be used as an education tool to educate children about snacks.
\end{abstract}

Keywords - education, game, snacks, making game, hygiene and healthy.

\section{INTRODUCTION}

Children are one of snacks enthusiasts. Usually, children like to buy snacks that can be found outside school. The snacks that can be found are fried foods, noodles, snack in the small plastic bag, ice, colourful candies, or tempura [1].

Children have high risk to become sick because of bad snacks [2]. The disease can be stomach ache until hepatitis A. This disease appears because there are so many snacks that are not hygienic and contain dangerous chemical substance. Even though there are not many snacks that are not hygienic and healthy, children have to pay more attention when choosing snacks that they will eat. They should not only focus on taste, display, and the price, but also hygiene and health..

Based on reference [1], all of respondents like to buy snacks outside school every day. They do not wash their hands before and after eating if they think their hands are still clean.

After giving questionnaire to children in elementary school, $70 \%$ of the respondents like to buy snacks outside school and 3\% do not know that they need to wash their hands before eating. $17 \%$ of the respondents do not know that they should use soap when washing their hands and 37\% do not know about the steps to wash their hands properly using soap and water.

Beside that, $47 \%$ of the respondents know the different about snacks that are hygienic and healthy based on the colour, $47 \%$ know the different based on the taste, and 73\% know the different based on the hygiene of the snacks.

For this reason, learning media should be made to educate children about choosing hygienic and healthy snacks. One of the 
learning media is games. Games are being choosen because children like games as games have pictures, colour, and visualisation which are interesting and suitable for children imagination [3]. Games can give positive impact if games is used properly for children.

Games that can be used as a learning media can be called as education games. Education games have an ability to reduce the boring effect of study [4]. Education games for children about how to choose snacks is rarely found. So making an education game about choosing hygienic and healthy snacks is a good idea. The game will have a goal to educate children about choosing hygienic and healthy snacks. This game will be named "Yummy Snack".

\subsection{Game}

\section{LITERATURE REVIEW}

Game can be used to study and be designed to have a goal play [5]. Game can be used as media to make player to have fun while playing and can involve player to study too [4].

Children like games [5] and can be used to train to solve the problems and conflicts [6]. Game can be called as an interactive media which can involve player to choose game story [7].

Games can be divided into varieties in genres, such as adventure, arcade, role play, simulation, strategy, and education [5] [8]. Adventure is a game's genre that has some challenges in one world to another world. Simulation is a game's genre that has a mission to face some objects that move fasts, dangerous, and can attack player. Role play is genre's game that mould player to become one with one of the characters. And simulation is a genre's game that simulate real life [9]. Strategy is a genre's game that needs strategy to play. And education is a genre's game that is designed as a learning material.

Based on the references[10], game with interesting visual can attract children. Story, colours, and pictures are being liked by children. With education games, without realizing, the knowledge will be absorbed easily when playing.

\subsection{Education Game}

Education games are games that have a learning material but fun. Education games can be used to increase language, thinking, social, and motoric abilities [11]. Education games are designed to train concentration and solving problem [12].

Education games can be used as an interactive learning media [13]. Education games are designed to have some elements like scoring, time, and reward when they win and punishment when they fail [8].

Education games have an advantage in their visualizations of the real problems [13]. Beside that, education games can help learning to become effective and efficient [6] and give motivation to player so they can study [14]. Education games can be an addition to fun aspects when studying [15]. The happier the player, the knowledge can be easily absorbed.

One of the examples of education game is LINE Pongpongpong. This game can be used to study basic mathematics. This game can be used to educate and entertain player [16].

Education games can be used for children who like to play games instead of studying [3]. By playing, children will be easily absorb new knowledge and can easily direct them to study [3].

\subsection{Game Engine}

Game engine is a software that is developed to make games [17]. Game engine has some tools that can be used to give the developer ease and speed in making game. Game engine then can produce video games that can be played on mobile, web browser, PC, or console [18].

Game engine can be divided into three: open source, freeware, and commercial [18]. Open source is one of the game engine's type that provides free game engine. For example, Cocos2d-x, Ogre3D, etc. Freeware is the game 
engine's type that can be used freely but there are some paid feature. For example, CryENGINE, Unreal Development Kit, etc. The last is commercial. Commercial is a paid game engine. For example, Game Maker Studio, etc.

\section{$2.4 \operatorname{Cocos} 2 d-x$}

Cocos $2 \mathrm{~d}-\mathrm{x}$ is one of the open source game engine. Cocos $2 \mathrm{~d}-\mathrm{x}$ is using $\mathrm{C}++$, Lua, and JavaScript programming language. But for the JavaScript one, it is named as Cocos2d-JS [19].

Basic feature that is always used is CCDirector, CCNode, CCScene, CCLayer, and CCSprite [20]. CCDirector sets all the scene in one game project. CCNode sets CCScene, CCLayer, CCSprite, and CCMenu.

CCScene sets scene on game, CCLayer sets layer on scene on game, CCSprite sets picture that can be displayed on layer. CCMenu sets menu that can be used on scene game.

\subsection{Visual Studio}

IDE or Integrated Development Environment is a toolbox that can help developer to work on a project easily [18]. IDE has their own library which can have some functions. One of the examples is Visual Studio.

Visual Studio is developed by Microsoft to make application with GUI or without GUI. Visual Studio can be used with programming language such as $\mathrm{C}, \mathrm{C \#}, \mathrm{C}++$, and Visual Basic. Visual Studio have two version; free and paid [18].

\section{RESEARCH METHODS}

This game is made by using $\operatorname{Cocos} 2 \mathrm{~d}-\mathrm{x}$ and Visual Studio. After the game has done, this game and a questionnaire that contain some questions will be giving out to 30 respondents that are children in elementary school. Some questions in questionnaire are about how good this game is and whether this game can give them more knowledge about choosing hygienic and healthy snacks or not. The result of this questionnaire can be a proof that this game can be used to educate children or not.

\section{RESULTS AND DISCUSSION \\ 4.1 Making the Game}

The game is made to educate children in choosing hygienic and healthy snacks. The game is named "Yummy Snack". After doing some data collections and data processing, designing gameplay, making game was started. Making game was started by making assets for game. Assets game contains buttons, menu, backgrounds, characters, and objects like the variety of snack that can be used in game based on snacks that children liked.

After making assets, the researcher then make programming of the game. Programming consists of GUI (Graphical User Interface) and mechanics. GUI programming consists of menu and HUD (Head Up Display). Mechanics programming consists of game systems.

GUI programming is a process to code game interfaces. GUI programming using Cocos2d-x uses CCSprite, CCMenuItemImage, and CCMenu. Code 4.1 shows the example of how to set sprite positions on Pause sprite.

\section{CCMenultemlmage $*$ pause $=$ CCMenultemImage::create ("PAUSE/pause.png", "PAUSE/pauseselected.png", this, menu_selector(SceneFour::pause)); \\ CCMenu $^{*}$ menu = CCMenu::create(pause, $\left.N U L L\right)$; pause->setPosition (ccp $(77,533))$; menu->setPosition(CCPointZero); this->addChild(menu, 1);}

Code 4.1 Example of GUI programming code

Mechanics programming is a process to code game systems. This systems consists of 6 scenes which uses mechanics programming. Code 4.2 shows the example of adding score when the choice is true and subtracting health when the choice is wrong.

void SceneOne::trueans(CCObject* $p$ Sender) 


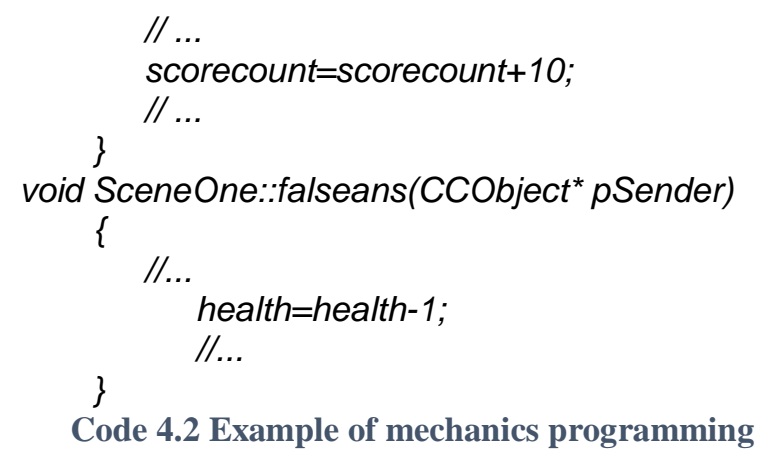

$/ / \ldots$

scorecount=scorecount +10 ;

$/ / \ldots$

\}

void SceneOne::falseans(CCObject ${ }^{\star}$ pSender)

\{

$/ / \ldots$

health=health-1;

I/...

\}

Code 4.2 Example of mechanics programming

\subsection{Explanations}

All of the stages on "Yummy Snack" game have their own purpose so it can reach the main purpose to educate children to choose hygienic and healthy snacks.

The first menu is encyclopaedia that is being named as Ensiklopedia. This menu contains additional knowledge. Ensiklopedia consists of 2 stages, the first is how to wash hands properly. The purpose of this stage is to educate children on how to wash hands properly with soap and water. Many children still do not know how to wash their hands properly and still carelessly eat snacks.

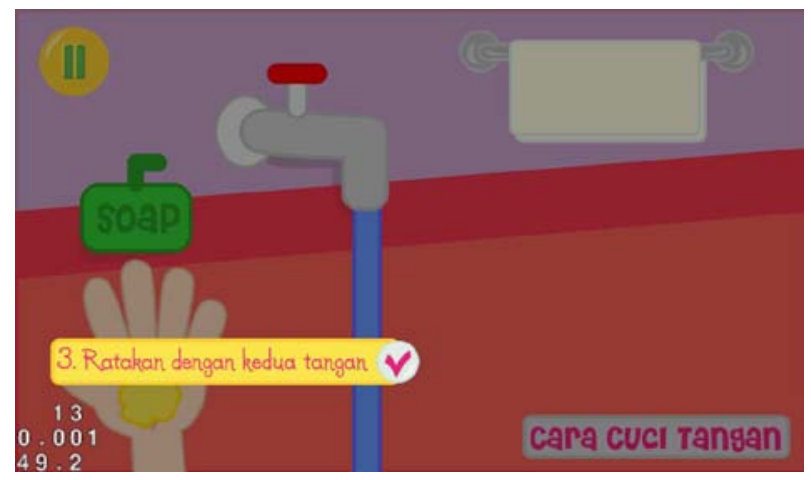

Fig. 4.1 Ensiklopedia: how to wash hands properly

The second stage is the variety of snacks, the characteristics of dangerous snacks, and the effect if we consume that. On this stage, the snacks that are being displayed are based on the research on what kind of snacks children like to eat [1]. The purpose of this stage is hopefully the children can be more careful on choosing snacks.

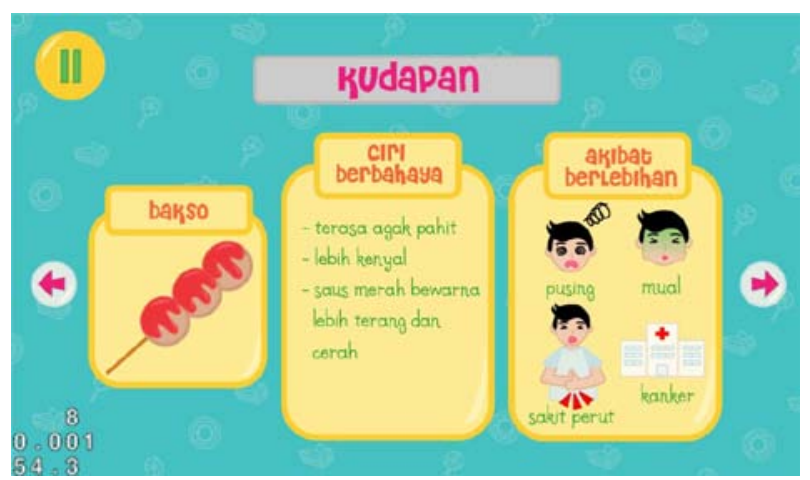

Fig. 4.2 Ensiklopedia: variety of snacks

The second menu is Games. This menu contains 4 stages of games. The first stage is a trivia games that contains 10 questions from 21 random questions. These questions are on information from Ensiklopedia. Player just chooses the right answer from the questions that are being displayed. The purpose of this stage is to make player know more the knowledge that are being displayed on Ensiklopedia.

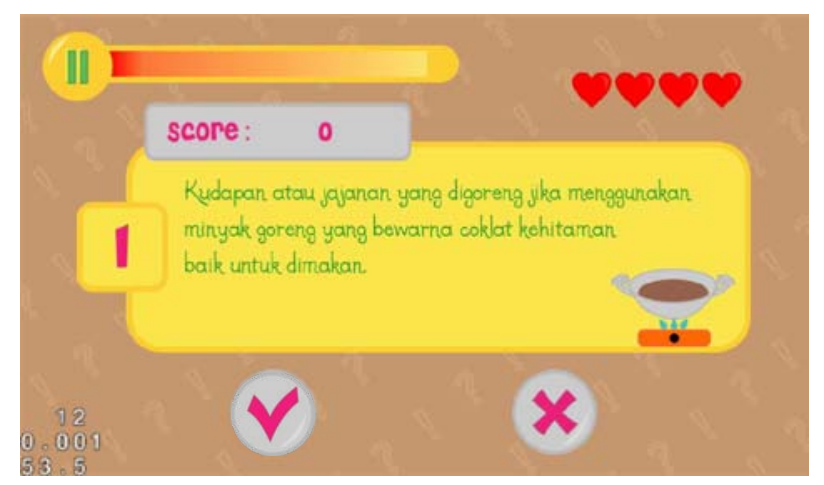

Fig. 4.3 Games: stage 1

The second stage of Games is when a player has to group the snacks that are being displayed to the right place. It illustrates whether the snacks is good or not based on the colour or the display. The purpose of this stage is, after playing this stage, children can pay more attention to the display of snacks which will be bought and consumed. 


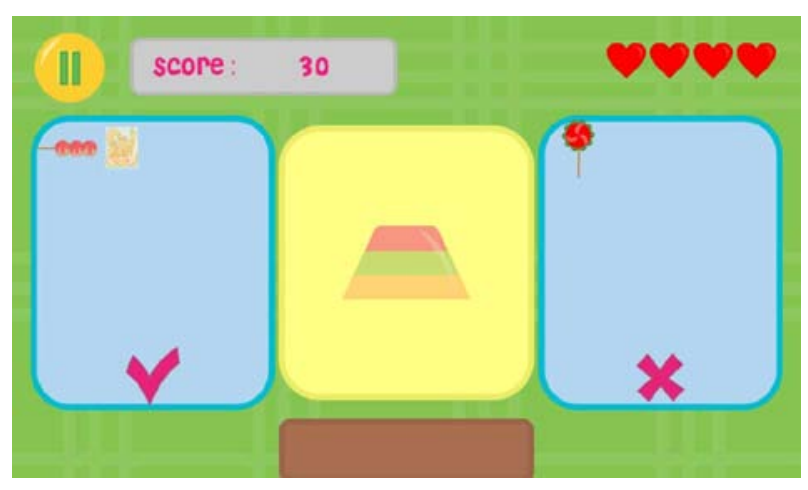

Fig. 4.4 Games: stage 2

On the third stage, a player will be playing by choosing one of the sellers that sell good snacks. This stage will display the characteristics of the seller and the player has to choose one that suits the criteria on the cleanest seller. This stage's purpose is to make children or player pay more attention on the seller hygiene.

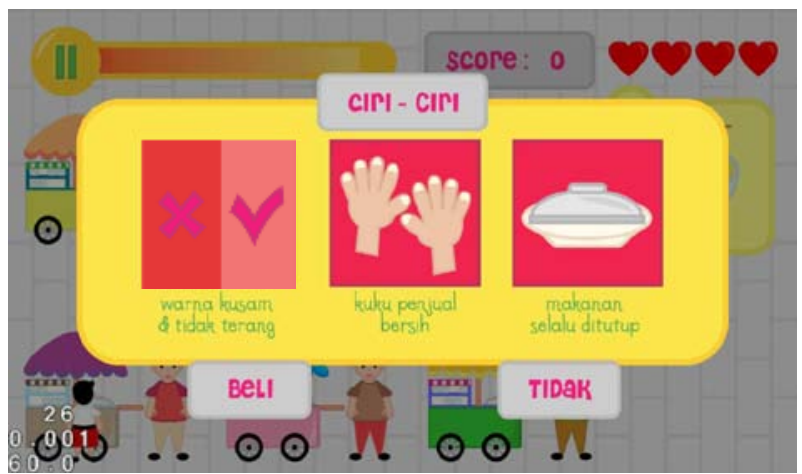

Fig. 4.5 Games: stage 3

On the last or the fourth stage, player has to choose the pair of cards that display good or right snacks. This stage purpose is to make player to pay more attention on the display of snacks.

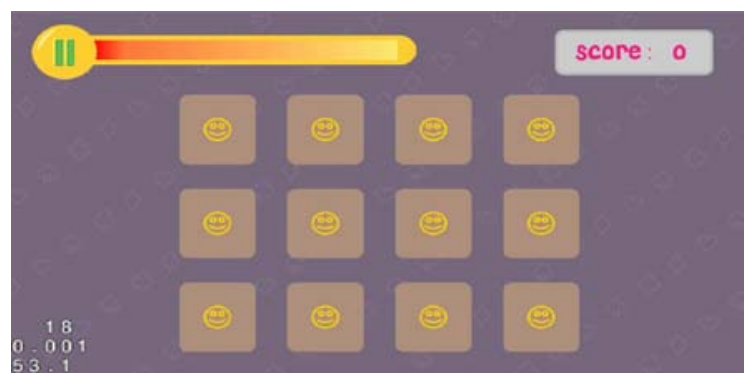

Fig. 4.6 Game: stage 4

\subsection{Results}

After the developing of the game is done, then game is given to 30 children in elementary school from 7 until 12 years old to find out whether this game has an impact or not.

The previous results in the paper about designing education game to choose hygiene and healthy snacks for children can be compared with this. The previous respondents and the respondents that are being used in this paper are the same person.

Before playing the game, $70 \%$ of the respondents knew the effect of eating too much snacks. After they play "Yummy Snack", the result increases to $80 \% ; 10 \%$ higher.

Before they played the game, only $70 \%$ of the respondents liked to pay attention the hygiene of the snacks seller. After they play the game, $80 \%$ of the respondents claimed that they paid attention to the hygiene of the snacks they want to buy and eat.

The next question is about how children know the different between good snacks and bad snacks. Based on the colour, $47 \%$ of the respondents knew that before playing the game. But after playing game, $70 \%$ know the difference based on the snack's colour.

Based on the taste $47 \%$ of the respondents knew the difference before playing the game. After playing the game, it becomes $67 \%$ of the children who know the difference.

Based on the hygiene of the snacks, 83\% of the children knew the difference before playing the game. After playing the game, $97 \%$ of the children know the different.

$83 \%$ of the children before playing the game knew that before eating snacks they have to wash their hands with soap. After playing the game, $97 \%$ of the children know that fact.

$37 \%$ of the children knew that there were some steps to wash hands properly before playing the game. After they play the game, $97 \%$ of the children know how to wash their hands properly. 
Beside that, children are required to grade "Yummy Snack" game. 20 children mark this game with 5 points or very good based on overall performance and feature. Based on the design, 14 children mark this game 4 points or good. And based on game model, 13 children mark with 5 point or very good.

\section{CONCLUSIONS}

"Yummy Snack" game can be used to educate children from 7 until 12 years old who are still studying in the elementary school about how to choose hygienic and healthy snacks. This can be seen from the increase of all point of aspects of knowledge about hygienic and healthy snacks before playing the game and after playing the game.

Formulation that can be used to educate children is by using encyclopaedia or the collection of additional knowledge about the simulation of washing hands with soap and choosing the variety of snacks that are usually consumed by children. The game provides the characteristics of dangerous snacks and the effects when they eat the snacks. Beside that, it can be added by some other games like how to differentiate snacks based on the display, how to decide the hygiene of snacks and how to choose the snack sellers. Using the method of learning by playing, , the knowledge can be absorbed easily.

\section{ACKNOWLEDGEMENT}

Vania Wahyu Febriani is a student from Information System department majoring at Game Technology in Soegijapranata Catholic University who received scholarship from Ministry of National Education of Republic Indonesia (Beasiswa Unggulan Kemendikbud Republik Indonesia).

\section{REFERENCES}

[1] I. Tristanti, "Perilaku Jajan Siswa SD IV Kedungdowo Kaliwungu, Kudus,” Maternal, vol. 12, no. 01, 2015.
[2] N. Noriko, E. Pratiwi, A. Yulita, and D. Elfidasari, "Studi Kasus terhadap Zat Pewarna, Pemanis Buatan dan Formalin pada Jajanan Anak di SDN Telaga Murni 03 dan Tambun 04 Kabupaten Bekasi,” Seri Sains dan Teknologi, vol. 1, no. 2, pp. 47-53, 2011.

[3] V. W. Febriani and T. B. Chandrawati, "Shooting Game Can be an Education Game for Children," International Journal of the Computer, the Internet and Management, vol. 20, no. SP2, pp. 8.1-8.6, 2012.

[4] V. W. Febriani, D. S. Ardityo, and R. Sanjaya, "Idea Development on Games of Education for School 's Entrepreneurship Sustainability," International Journal of the Computer, the Internet and Management, vol. 22, no. SP2, pp. 9.1-9.7, 2014.

[5] D. Hardianto, "Pemanfaatan Software Komputer untuk Meningkatkan Kecerdasan Emosi (EQ) Anak,” 2012.

[6] A. Putranto and P. T. Informatika, "Pengembangan Game Edukasi Klasifikasi Hewan Menggunakan Adobe Flash Profesional CS 5 sebagai Media Pembelajaran Biologi Kelas VII SMP N 15 Yogyakarta,” 2013.

[7] M. S. Pramono, A. Paramita, and U. Muzakiroh, "Pengembangan Permainan Multimedia Interaktif tentang Perilaku Hidup Bersih dan Sehat pada Siswa Sekolah Dasar," Buletin Penelitian Kesehatan, vol. 39, no. 4 Des, 2011.

[8] M. J. P. Wolf, "Genre and The Video Game," The medium of the video game, pp. 113-134, 2002.

[9] Anonim, "Video Game Genres.” [Online]. Available:

http://tvtropes.org/pmwiki/pmwiki.php/M ain/VideoGameGenres. [Accessed: 30Apr-2015].

[10]F. Noviyanto, “Membangun sistem pembelajaran pengenalan bentuk untuk anak berbasis multimedia dan game 
interaktif,” Jurnal Informatika, vol. 2, no. 1, pp. 158-167, 2012.

[11]M. Rohwati, "Penggunaan Education Game untuk Meningkatkan Hasil Belajar IPA Biologi Konsep Klasifikasi Makhluk Hidup,” Jurnal Pendidikan IPA Indonesia, vol. 1, no. 1, pp. 75-81, 2012.

[12] S. Hafsari, I. Kuswardayan, and R. R. Hariadi, "Pembuatan Game Simulasi Multiplayer Online 'Freelance Simulation' Berbasis Web dengan Kerangka Kerja CodeIgniter,” Teknik Pomits, vol. 2, no. 1, pp. 1-6, 2013.

[13]S. E. Dyta, "Rancang Bangun Aplikasi Game Edukasi Anak untuk Mengenal Bentuk dan Warna Benda,” 2013.

[14] M. Pivec, A. Koubek, and C. Dondi, Guidelines for Game-based Learning. Germany: Pabst Science Publisher, 2004.

[15] M. H. Oermann and K. Heinrich, Annual Review of Nursing Education: Strategies for Teaching, Assessment, and Program Planning, 3rd ed. New York: Springer Publishing Company, Inc., 2005.
[16]V. W. Febriani and N. A. Wijaya, "High School Technopreneurship Program to Increase the Educational Games for Students," International Journal of the Computer, the Internet and Management, vol. 22, no. SP1, p. 25.1, 2014.

[17] J. Calvo Villazón, "Strategy2D: Turnbased Strategy Video Game Engine for Mobile Devices,” 2014.

[18] P. Stafford, "Location Racing - Research Document," 2013. [Online]. Available: http://glasnost.itcarlow.ie/ softeng4/C001 39462/documents/01. Location Racing Research Document - Final.pdf. [Accessed: 21-May-2015].

[19] F. Hussain, A. Gurung, and G. Jones, Cocos2d-x Game Development Essentials. Brimingham, UK: Packt Publishing Ltd., 2014.

[20]A. Abdul-Karim and L. Karlsson, "Game Development Project with Cocos2D-X," Helsinki: Metropolia Ammattikorkeakoulu, 2014. 